\title{
Age and Gender Depending Growth of Feathers and Feather-Free Body in Modern Fast Growing Meat-Type Chickens
}

\author{
Christian Wecke, Daulat Rehman Khan, Angela Sünder, Frank Liebert \\ Division Animal Nutrition Physiology, Department of Animal Sciences, Georg-August-University of Göttingen, \\ Göttingen, Germany \\ Email: flieber@gwdg.de
}

How to cite this paper: Wecke, C., Khan, D.R., Sünder, A. and Liebert, F. (2017) Age and Gender Depending Growth of Feathers and Feather-Free Body in Modern Fast Growing Meat-Type Chickens. Open Journal of Animal Sciences, 7, 376-392.

https://doi.org/10.4236/ojas.2017.74029

Received: July 3, 2017

Accepted: September 10, 2017

Published: September 13, 2017

Copyright $\odot 2017$ by authors and Scientific Research Publishing Inc. This work is licensed under the Creative Commons Attribution International License (CC BY 4.0).

http://creativecommons.org/licenses/by/4.0/

\begin{abstract}
Two growth experiments with fast growing meat type chickens (Ross 308) were conducted to assess the growth of feathers and feather-free body dependent on age and gender (male:female ratio $=1: 1$ ). Birds were reared under uniform management and feeding conditions (floor pens; 15 pens per gender; 5 birds per pen) during the starter (day 1 to 22) and grower period (day 22 to 36). Diets were based on corn, wheat, soybean meal, soybean protein concentrate and balanced with feed amino acids to ensure an equal feed protein quality close to the ideal amino acid ratio by a constant mixture of the feed proteins. At start of the experiment and further on weekly up to the end of the $5^{\text {th }}$ week, 15 birds per gender (each 3 pens of 5 birds) were selected and $24 \mathrm{~h}$ fasted before quantitative de-feathering. Both feather and feather free body fractions were significantly increased with increasing age of the birds $(p<$ $0.001)$. Feather percentage as related to the empty body weight increased non-linearly from approximately $2 \%$ at the end of the first week to about $4 \%$ at the end of the experiment. Feather percentage and dry matter content of the feather-free body was significantly higher in female birds $(p<0.001)$ as compared to males. Further investigations will show how this varying proportions impact on nutrient deposition of modern meat-type chickens dependent on age and gender, respectively.
\end{abstract}

\section{Keywords}

Growing Chickens, Feather Percentage, Feather-Free Body, Age, Gender

\section{Introduction}

Investigations about whole body composition of current broiler genotypes pro- 
vide preconditions for valid evaluation of energy and nutrient requirements, namely when factorial methods are applied. In this context, both maintenance requirement and nutrient deposition data are needed for valid conclusions. Consequently, changes of the proportion between feather and feather-free body fractions during growth are of special importance for revision of such requirement data when based on factorial methods. According to our knowledge, first detailed investigations about feather and feather-free body mass both depending on genotype and age were reported by Lehmann [1] [2]. However, corresponding data of actual broiler genotypes are missed.

Several studies are indicating that feathers achieve their mature state earlier than the remaining body fractions [3] [4] [5]. Wylie et al. [6] concluded that feather growth was apparently maintained in preference to muscle and body development. Generally, the growth rate of any body tissue is resulting from balance between synthesis and degradation of proteins, but once formed feather protein is not underlying turnover processes. Therefore, inadequate nutrient supply impacted on the proportionate feather covering by lower gain of the remaining body mass. Wylie et al. [7] pointed out that dietary crude protein (CP) was preferentially partitioned for feather production rather than for muscle growth in a modern turkey line. It was concluded that feather growth is maintained as high as possible on the expense of body growth when feed supply was below the need for optimal performance data. Consequently, the nutrient consumption for feather development is a significant factor of high nutritional priority during the period of rapid growth.

As reviewed both by Deschutter and Leeson [8] and Leeson and Walsh [9], several factors of influence like animal, nutritional, environmental and management factors may respond on feather growth and development. Accordingly, significant differences in feather development and rate of feathering between genotypes of growing chicken and laying hens were reported [1] [2] [10]-[17]. Among nutritional factors, the dietary $\mathrm{CP}$ and amino acid (AA) supply is the most important [17]-[25]. Reduced feather development as well as abnormal feather structure and pigmentation was observed due to suboptimal AA supply [26]-[32]. In addition, feather coverage of birds with naked-neck and fizzle gene is considerably lower as compared to their "fully-feathered" counterparts [16] [20] [33]-[40]. Furthermore, time-dependent plumage development of birds with early and late feathering genes is to be taken into account [41] [42].

The present study aimed to generate a revised database of feather and feather-free body mass development in modern meat-type chickens which may contribute to explain variation in age and gender depending nutrient requirements.

\section{Materials and Methods}

Two consecutive growth experiments utilized 180 growing chicken (male to female birds = 1:1) and were conducted at the facilities of the Division Animal Nutrition Physiology, Department of Animal Sciences of Georg-August-University 
Gottingen. Each experiment lasted 5 weeks and was approved by the Lower Saxony Federal Office for Consumer Protection and Food Safety (LAVES), Germany.

\subsection{Animals and Housing}

Day old meat-type chickens (ROSS 308) were obtained from a commercial hatchery and kept in floor pens on wood shavings. Free supply of a standard diet and water was provided. Next day (d1), averaged weighed birds were randomly allotted to 15 pens per gender (1.2 sqm; 5 birds per pen) and kept under uniform management and feeding conditions (starter period: 1 to $22 \mathrm{~d}$, grower period: 22 to $36 \mathrm{~d}$ ). Room temperature was gradually reduced from $32^{\circ} \mathrm{C}$ to $20^{\circ} \mathrm{C}$ with increasing age of the birds. Humidity was maintained between $60 \%$ and $70 \%$ and light was provided for 23 hours per day.

\subsection{Diets and Feeding}

The starter and grower diet (Table 1) was based on corn, wheat, soybean meal,

Table 1. Composition of experimental diets ( $\mathrm{g} / \mathrm{kg}$ as fed).

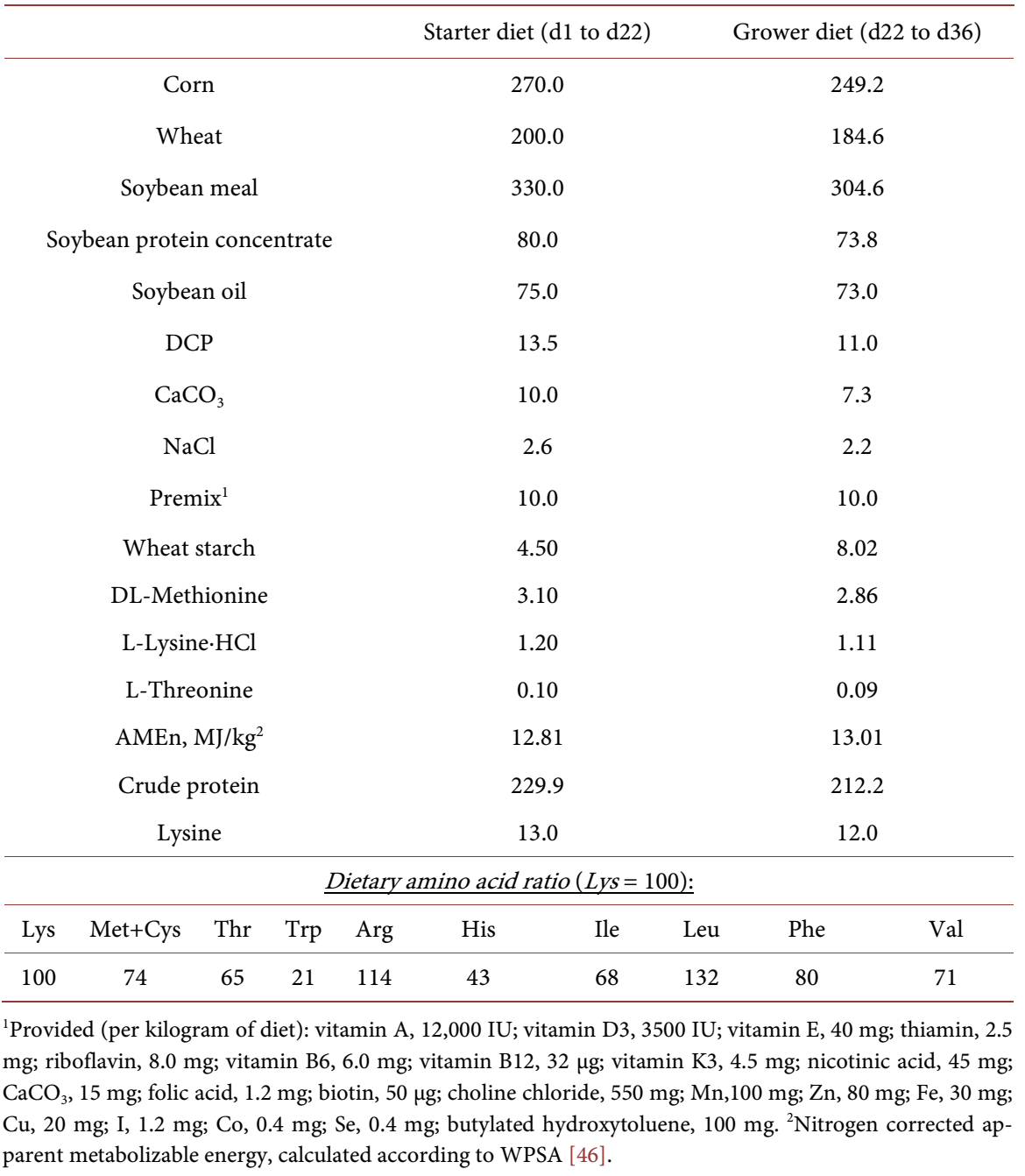


soybean protein concentrate and crystalline feed AA as main ingredients. Diet formulation aimed to meet current recommendations of NRC [43] and GRRS [44]. A constant mixture of the dietary protein sources yielded equal feed protein quality during both of the feeding periods. Based on the analysed AA content of the individual feed ingredients (see 2.4.), the AA composition of final diets was adjusted close to the ideal AA ratios (IAAR) as proposed by Wecke and Liebert [45]. In case of histidine, leucine and phenylalanine the observed individual AA ratios to lysine exceeded the IAAR due to the elevated content in the ingredients.

Birds had free access both to drinking water and pelletized starter and grower diets.

\subsection{Collection and Sampling}

Both at start of the experiment and weekly up to the end of the $5^{\text {th }}$ week 15 male and female birds ( 3 pens per week and gender) were selected by body weight (BW) and fasted for 24 hours with full access to drinking water. Selected birds were euthanized by $\mathrm{CO}_{2}$ inhalation according to animal welfare regulations. Fresh feather mass from manual individual feather plucking was quantified by weight before and after plucking. Each sample of quantitatively collected feathers and of feather-free body was separately stored in plastic bags at $-20^{\circ} \mathrm{C}$ for further processing. Differing from this procedure, the removed down from day-old chickens were pooled due to the low individual feather quantity.

Feather sample bags were perforated and freeze dried for $48 \mathrm{~h}$. Following freeze drying, feathers were weighed, roughly cut with scissors and milled with added dry ice in a laboratory mill. Finally, the samples were grinded in a hammer mill with dry ice to pass a $1 \mathrm{~mm}$ sieve. These powdered feather samples were applied for proximate chemical analyses.

The feather-free empty bodies were carefully defrosted, autoclaved for $4 \mathrm{~h}$ at $110^{\circ} \mathrm{C}$ (HMC Europe GmbH, Germany) and pooled in three replicates of 5 birds per pen. Pooled samples were cut into small pieces to pass through the meat chopper. The resulting mince was carefully homogenized and a representative sample was taken for further analyses.

\subsection{Chemical Analyses}

Feed ingredients, diets, feathers and feather-free empty bodies were analysed in duplicates according to the German standard procedures [47]. $\mathrm{N}$ analyses were conducted by DUMAS-method (LECO ${ }^{\circledR}$ TruMac, LECO Instrument GmbH, Kirchheim, Germany) and CP was calculated with factor 6.25. AA composition of the feed protein sources (except tryptophan) was analysed by ion-exchange chromatography (Biochrom ${ }^{\circledR}$ 30, Biochrom Ltd. Cambridge, England) following acid hydrolysis without and with application of an oxidation step for quantitative determination of sulphur containing AA (SAA). Tryptophan was quantified by reverse phase high performance liquid chromatography and fluorometric de- 
tection following alkaline hydrolysis with barium hydroxide during autoclaving $\left(16 \mathrm{~h}, 120^{\circ} \mathrm{C}\right)$.

\subsection{Statistical Analyses}

Statistical analyses run with SPSS software package (Version 23.0 for Windows; IBM SPSS Statistics Inc., Chicago, IL, USA). Individual outlier data were identified $(p \leq 0.05)$ by explorative data analysis using the interquartile range (IQR) for outliers (values between 1.5 IQR's and 3 IQR's from the end of a box) and extreme values (more than 3 IQR's from the end of a box) of the boxplot function. Two-way analysis of variance (ANOVA) was performed to compare means of variables depending both on age and gender of broiler chickens as main effects, inclusive their interactions. Verification of variance homogeneity (evaluated by Levene-Test) and identification of significant differences ( $p \leq 0.05)$ applied Games-Howell test and Tukey post-hoc test, respectively. Nonlinear regression analysis was utilized to demonstrate the age-dependent variation of both the feather percentage and the dry matter (DM) content of the body fractions.

\section{Results}

Data of BW, feather weight and feather percentage in male and female birds of the two hatches are summarized in Table 2. According to the biological process of growth, both body and feather mass were significantly increased with increasing age of the birds $(p<0.001)$. At the end of the first week of age, feather

Table 2. Body and feather weight data and feather percentage depending on age and gender of fast growing broiler chickens ${ }^{1}$.

\begin{tabular}{|c|c|c|c|c|c|c|c|c|}
\hline \multirow[t]{2}{*}{ Age (d) } & \multicolumn{2}{|c|}{$\begin{array}{l}\text { Whole body } \\
\text { weight (g) }\end{array}$} & \multicolumn{2}{|c|}{$\begin{array}{l}\text { Empty body } \\
\text { weight }^{2}(\mathrm{~g})\end{array}$} & \multicolumn{2}{|c|}{$\begin{array}{c}\text { Feather } \\
\text { weight (g) }\end{array}$} & \multicolumn{2}{|c|}{$\begin{array}{c}\text { Feathers (\% of } \\
\text { empty body) }\end{array}$} \\
\hline & Female & Male & Female & Male & Female & Male & Female & Male \\
\hline 1 & 45.1 & 46.6 & 42.0 & 43.0 & 1.4 & 1.3 & 3.34 & 2.95 \\
\hline 8 & 180 & 195 & 154 & 170 & 2.9 & 4.3 & 1.85 & 2.54 \\
\hline 15 & 437 & 516 & 392 & 475 & 9.7 & 16.3 & 2.38 & 3.42 \\
\hline 22 & 952 & 1045 & 866 & 964 & 28.3 & 35.9 & 3.26 & 3.72 \\
\hline 29 & 1749 & 1655 & 1632 & 1534 & 53.8 & 62.6 & 3.28 & 4.10 \\
\hline $36^{3}$ & 2499 & 2437 & 2305 & 2278 & 83.1 & 91.7 & 3.61 & 4.04 \\
\hline \multirow[t]{2}{*}{ Mean } & 990 & 975 & 910 & 904 & 30.3 & 35.1 & 2.97 & 3.47 \\
\hline & \multicolumn{8}{|c|}{$\underline{A N O V A \text { significance levels }(p)}$} \\
\hline Age (A) & \multicolumn{2}{|c|}{$<0.001$} & \multicolumn{2}{|c|}{$<0.001$} & \multicolumn{2}{|c|}{$<0.001$} & \multicolumn{2}{|c|}{$<0.001$} \\
\hline Gender $(G)$ & \multicolumn{2}{|c|}{$=0.746$} & \multicolumn{2}{|c|}{$=0.433$} & \multicolumn{2}{|c|}{$<0.001$} & \multicolumn{2}{|c|}{$<0.001$} \\
\hline$A \times G$ & \multicolumn{2}{|c|}{$=0.006$} & \multicolumn{2}{|c|}{$=0.003$} & \multicolumn{2}{|c|}{$=0.011$} & \multicolumn{2}{|c|}{$<0.001$} \\
\hline
\end{tabular}

${ }^{1} \mathrm{n}=15$ per age period and gender. ${ }^{2}$ Body weight following $24 \mathrm{~h}$ feed deprivation. ${ }^{3}$ Final body weight of male birds was determined at $35 \mathrm{~d}$ of age. 
weight and relative feather percentage data of female birds were significantly higher $(p<0.001)$ as compared to their male counterparts. For both criteria, highly significant two-way interaction between age and gender was identified. Means of feather percentage as related to the empty BW increased from approximately $2 \%$ at the end of the first week to about $4 \%$ at the end of the experiment.

In Figure 1, the individual feather percentage data are summarized. In spite of the high individual variation and except day 1 , the rate of feathering is obviously higher in female birds. Fitted plots of feather percentage as function of empty BW depending on gender yielded very similar curve approximations. Superior adaptation of both trend-lines and highest correlation were observed when the data from day old broiler chickens were excluded and a non-linear power function was approximated.

DM related data (Table 3) show a significant increase of feather percentage from $4.6 \%$ at the end of the $1^{\text {st }}$ week to approximately $7 \%$ at the end of the $5^{\text {th }}$ week $(p<0.001)$. However, no significant gender effect was observed $(p>0.05)$ when data were DM related. This observation can be explained by high standard deviations and different DM content in feathers and de-feathered body fractions. Except at d1, the DM content of feathers varied between $40 \%$ and $60 \%$, but only $20 \%$ to $32 \%$ DM were analysed in feather-free body fractions. Superior DM contents were found in the down feathers of birds at $\mathrm{d} 1$ (approximately $70 \%$ ), but contents declined subsequently up to the end of the $3^{\text {rd }}$ week. A continuous increase of DM content in feathers was observed up to the end of the $5^{\text {th }}$ week. The age-dependent differences were significant $(p<0.001)$, but no significant gender effect was observed for DM content of feathers $(p>0.05)$.

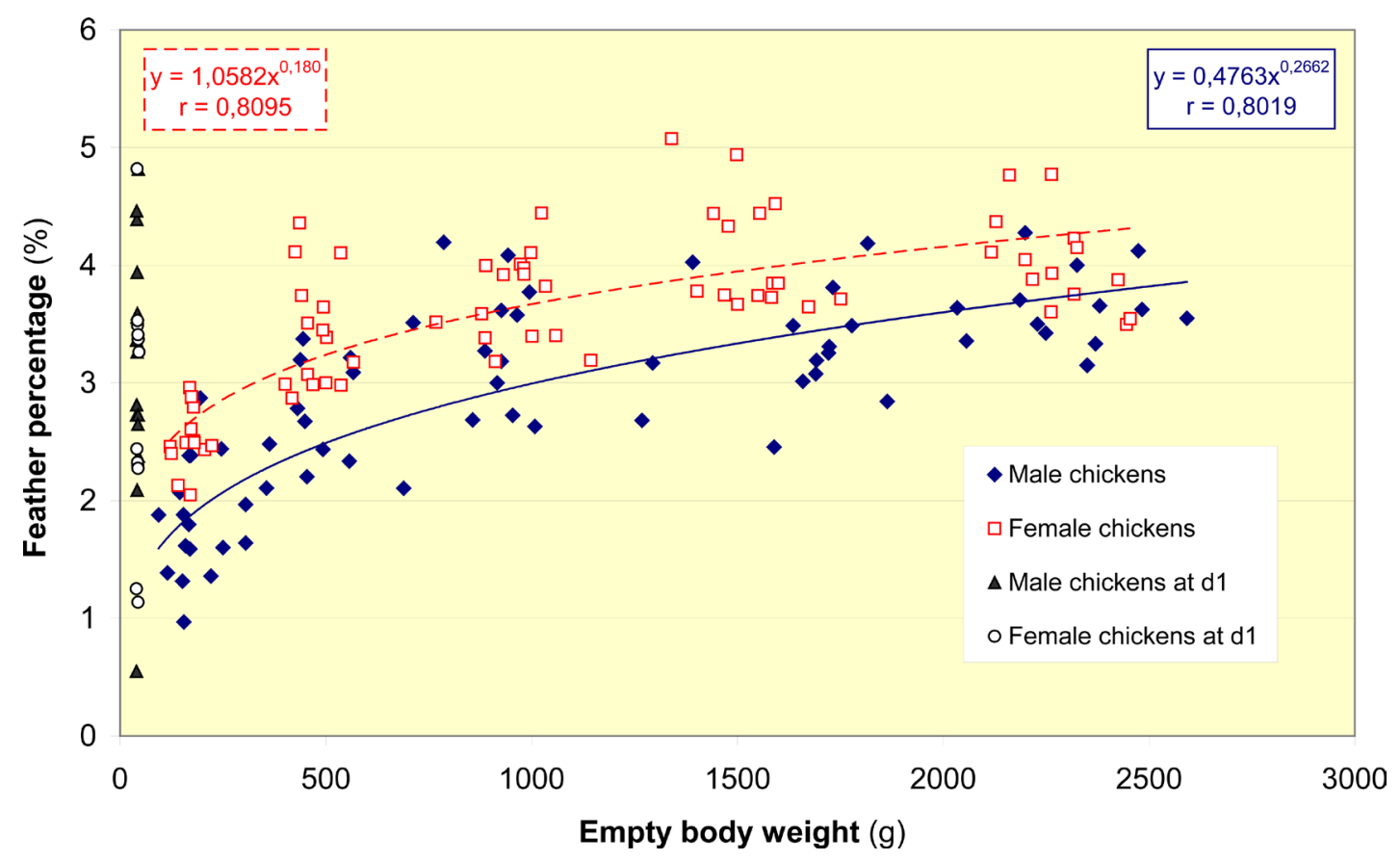

Figure 1. Feather weight as a proportion of the empty body weight of male and female broiler chickens. 
Table 3. Dry matter (DM) content of body fractions and feather DM percentage depending on age and gender of fast growing broiler chickens ${ }^{1}$.

\begin{tabular}{|c|c|c|c|c|c|c|c|c|}
\hline \multirow[t]{2}{*}{ Age (d) } & \multicolumn{2}{|c|}{$\begin{array}{c}\text { Empty } \\
\text { body }^{2}(\%)\end{array}$} & \multicolumn{2}{|c|}{$\begin{array}{c}\text { Feather-free } \\
\text { body }(\%)\end{array}$} & \multicolumn{2}{|c|}{ Feathers $^{3}(\%)$} & \multicolumn{2}{|c|}{$\begin{array}{c}\text { Feather DM } \\
\text { (\% of empty body } \\
\text { DM) }\end{array}$} \\
\hline & Male & Female & Male & Female & Male & Female & Male & Female \\
\hline 1 & 21.43 & 21.37 & 19.62 & 20.02 & 76.78 & 65.98 & 11.32 & 9.09 \\
\hline 8 & 25.38 & 26.15 & 24.70 & 25.62 & 56.72 & 45.74 & 4.67 & 4.57 \\
\hline 15 & 27.20 & 29.08 & 26.86 & 28.56 & 40.85 & 43.62 & 3.70 & 5.13 \\
\hline 22 & 28.64 & 30.21 & 28.16 & 29.68 & 42.39 & 43.81 & 5.00 & 5.40 \\
\hline 29 & 30.28 & 32.10 & 29.69 & 31.33 & 47.34 & 50.39 & 5.20 & 6.41 \\
\hline $36^{4}$ & 30.62 & 33.46 & 29.79 & 32.31 & 52.07 & 60.38 & 6.30 & 7.41 \\
\hline Mean & 27.98 & 29.65 & 27.33 & 28.91 & 49.68 & 49.86 & 5.37 & 5.99 \\
\hline $\mathrm{SD}^{5}$ & 2.64 & 3.38 & 2.82 & 3.35 & 9.44 & 7.86 & 1.86 & 1.32 \\
\hline \multicolumn{9}{|c|}{ ANOVA significance levels $(p)$} \\
\hline Age (A) & & $<0.001$ & & $<0.001$ & & .001 & & \\
\hline Gender $(G)$ & & $<0.001$ & & $<0.001$ & & 205 & & \\
\hline$A \times G$ & & $=0.004$ & & $=0.074$ & & .001 & & \\
\hline
\end{tabular}

${ }^{1} n=3$ pooled samples of each five birds per age period and gender. ${ }^{2}$ Body weight following $24 \mathrm{~h}$ feed deprivation. ${ }^{3} \mathrm{At} 1 \mathrm{~d}$ of age only one pooled feather sample of each gender due to the low feather yield per bird. ${ }^{4}$ Final body weight of male birds was determined at $35 \mathrm{~d}$ of age. ${ }^{5}$ Standard deviation.

Consequently, all feather DM data related to the empty BW were plotted in Figure 2. Superior correlation between DM content of feathers and empty BW was achieved by application of a quadratic function, but only when data from $\mathrm{d} 1$ and $\mathrm{d} 8$ were excluded. Due to the limited quantity of collected down feathers at $\mathrm{d} 1$ and only one sample available for DM analysis per gender, these data need further validation. In addition, including data of male and female birds at $\mathrm{d} 8$ yielded a strong decline of the coefficient of the regression function $(r=0.7308)$.

Contrary, the DM content both in the feather-free and whole empty body (Table 3 ) increased continuously from $20 \%-21 \%$ at start up to $31 \%-32 \%$ at the end of the experiment $(p<0.001)$. The body of female birds contained significantly more DM as compared to the males $(p<0.001)$. The gender-specific correlations between DM content in the feather-free body and the empty BW are summarized in Figure 3.

\section{Discussion}

The nonlinear increase of feather growth with increasing age of actual fast growing meat-type chickens seems to be higher as compared to previous genotypes which yielded about $50 \mathrm{~g}$ feather per bird at market age, as reviewed by Leeson and Walsh [48]. According to our results (Table 2), a total of 80 to $90 \mathrm{~g}$ feathers per bird can be expected at the commercial slaughter age of 5 weeks. Higher individual feather yields between 110 and $130 \mathrm{~g}$ were observed in older birds (Table 4). 


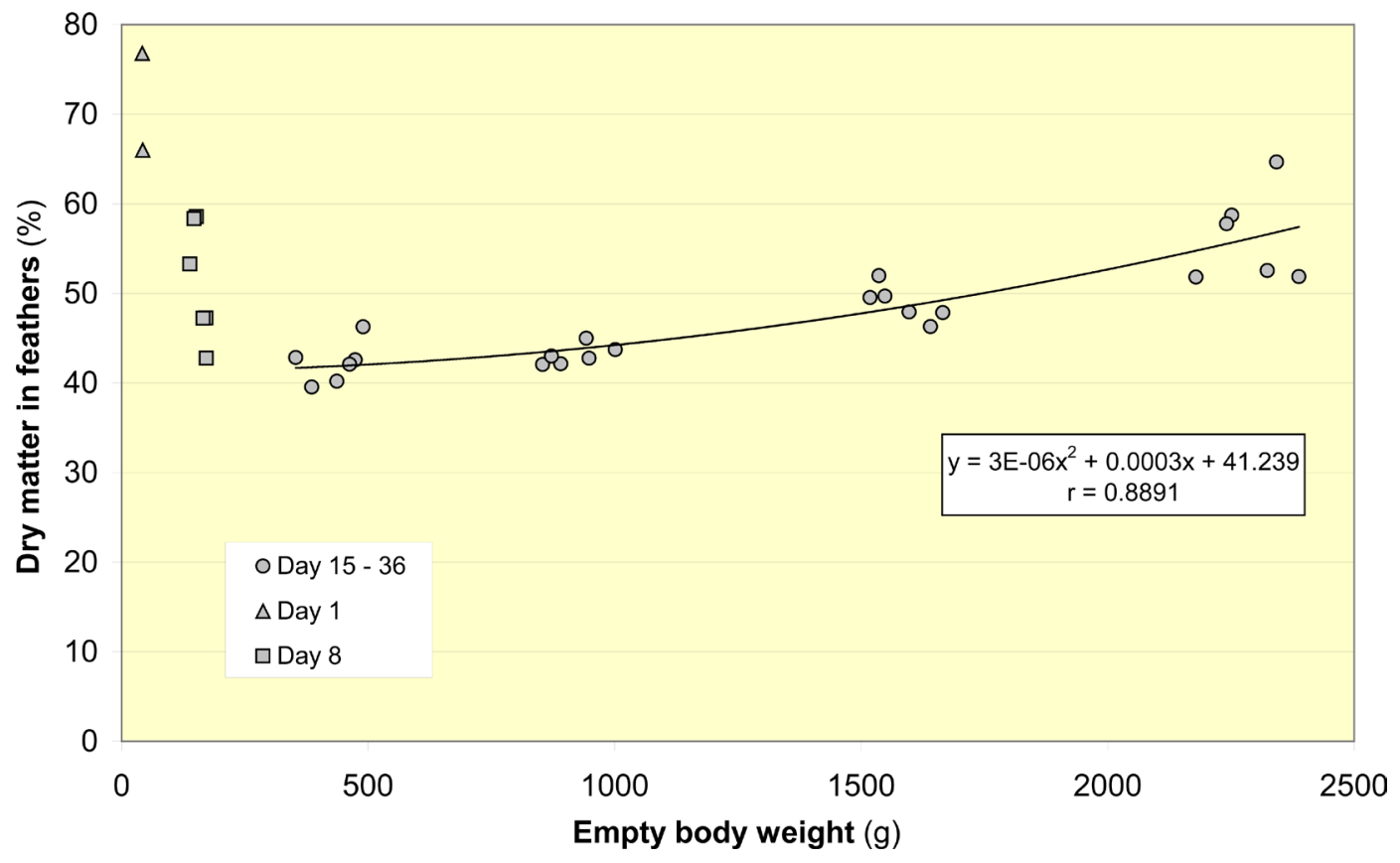

Figure 2. Dry matter content of feathers related to the empty body weight of male and female broiler chickens.

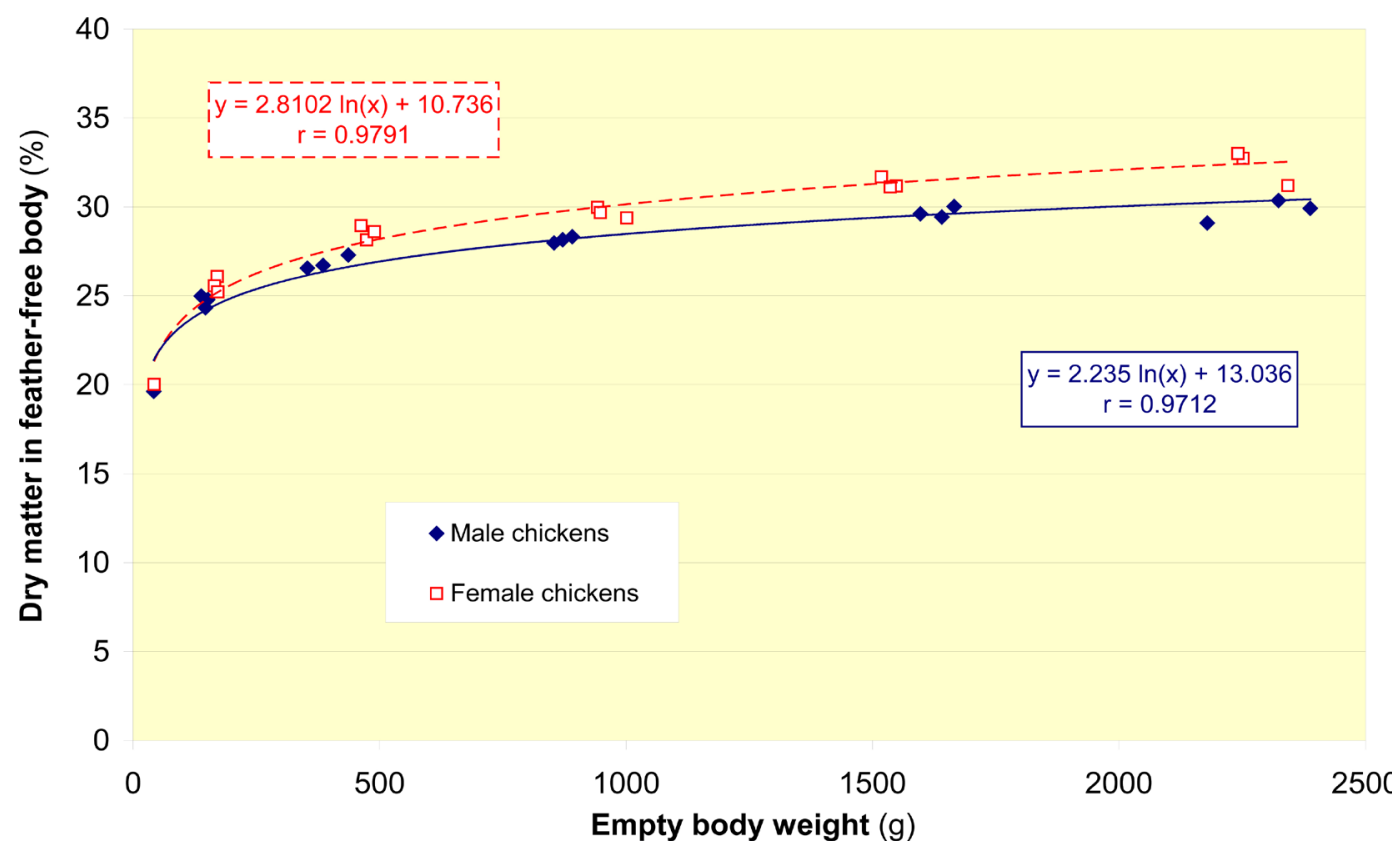

Figure 3. Dry matter content of the feather-free body related to the empty body weight of broiler chickens dependent on gender.

Wheeler and Latshaw [49] observed the beginning of rapid feather growth up to the end of the $2^{\text {nd }}$ week of age. Sheridan and McDonald [41] stated the competition between feather and body growth as most pronounced during the first weeks of life. However, to our knowledge reliable quantitative data on feather weight of male and female chicken up to the $2^{\text {nd }}$ week of age are scarcely reported. The growth rate of feathers is reported to be the highest during the first 6 
Table 4. Summarized feather percentage data of normally feathered male (M) and female (F) broiler chickens depending on age taken from reported experimental data.

\begin{tabular}{|c|c|c|c|c|c|c|}
\hline Age & Gender & $\begin{array}{c}\text { Total body weight } \\
\text { (g) }\end{array}$ & $\begin{array}{c}\text { Feather weight }{ }^{1} \\
\text { (g) }\end{array}$ & Feather percentage (\%) & Reference basis ${ }^{2}$ & Literature source \\
\hline $49 \mathrm{~d}$ & $M+F$ & $1624-1708$ & & $3.4-4.0$ & ... starved BW & [18] \\
\hline $45 \mathrm{~d}$ & M & $1783-1803$ & $121-124$ & $6.7-6.9$ & \multirow{4}{*}{... full-fed live weight } & \multirow{4}{*}{ [19] } \\
\hline $52 \mathrm{~d}$ & $\mathrm{~F}$ & $1692-1722$ & $125-128$ & $7.3-7.5$ & & \\
\hline $44 \mathrm{~d}$ & M & $1769-1771$ & $116-121$ & $6.6-6.8$ & & \\
\hline $52 \mathrm{~d}$ & $\mathrm{~F}$ & $1700-1714$ & $116-122$ & $6.9-7.1$ & & \\
\hline $39 \mathrm{~d}$ & M & $1929-2065$ & \multirow{4}{*}{$71-81(\mathrm{DM})$} & $5.91-6.00^{4}$ & \multirow{2}{*}{... empty BW after $18 \mathrm{~h}$ food removal } & \multirow{2}{*}[12]{} \\
\hline $49 \mathrm{~d}$ & M & $2510-2727^{3}$ & & $5.66-6.07^{4}$ & & \\
\hline $48 \mathrm{~d}$ & M & $1992-2212$ & & $4.73-6.10$ & \multirow{2}{*}{... starved live weight } & \multirow{2}{*}[42]{} \\
\hline $48 \mathrm{~d}$ & $\mathrm{~F}$ & $1683-1783$ & & $5.19-5.75$ & & \\
\hline $6 \mathrm{wk}$ & $M+F$ & 1895 & 111.5 & 5.92 & \multirow{2}{*}{... final whole BW } & \multirow{2}{*}{ [35] } \\
\hline & & & $61.5(\mathrm{DM})$ & $3.26(\mathrm{DM})$ & & \\
\hline $28 \mathrm{~d}$ & \multirow{2}{*}{ M } & 656 & $38.8^{5}$ & 5.91 & & \multirow{2}{*}[20]{} \\
\hline $42 \mathrm{~d}$ & & $1301^{5}$ & $86.8^{5}$ & $6.67^{5}$ & & \\
\hline \multirow{2}{*}{$7 \mathrm{wk}$} & M & $1954-2576$ & & $4.45-4.80$ & \multirow{2}{*}{... final whole BW } & \multirow{2}{*}[15]{} \\
\hline & $\mathrm{F}$ & $1700-2167$ & & $4.92-5.36$ & & \\
\hline $49 \mathrm{~d}$ & $M+F$ & 2003 & & 4.66 & ... final whole BW & [36] \\
\hline $7 \mathrm{wk}$ & & 1771 & & 5.7 & \multirow{2}{*}{... BW at slaughter } & \multirow{2}{*}[16]{} \\
\hline $8 \mathrm{wk}$ & & 2151 & & 6.0 & & \\
\hline \multirow[t]{2}{*}{$6 \mathrm{wk}$} & & 1895 & 111.5 & 5.92 & \multirow{4}{*}{... BW after $24 \mathrm{~h}$ without feed } & \multirow{2}{*}[37]{} \\
\hline & & & $61.5(\mathrm{DM})$ & $3.26(\mathrm{DM})$ & & \\
\hline $7 \mathrm{wk}$ & M & 1786 & & 5.34 & & [38] \\
\hline $7 \mathrm{wk}$ & $\mathrm{F}$ & 1462 & & 6.11 & & \\
\hline $21 \mathrm{~d}$ & M & $710-779$ & $71.0-75.7$ & $9.51-10.10$ & ... final whole BW & [21] \\
\hline $21 \mathrm{~d}$ & M & & $5.1-10.1$ & $1.0-1.5$ & ... final whole BW & {$[22]$} \\
\hline $37 \mathrm{~d}$ & M & 2006 & 112 & $5.6^{5}$ & $\ldots \mathrm{BW}$ at slaughter & [39] \\
\hline
\end{tabular}

${ }^{1}$ Lowest and highest average body weight (BW) and feather weight data of the experimental groups. ${ }^{2}$ Feather weight expressed as a percentage of .... ${ }^{3}$ Empty body weight (BW). ${ }^{4} 2.86 \%-3.01 \%$ and $2.60 \%-3.03 \%$ feather dry matter (DM), respectively. ${ }^{5}$ Calculated values based on published body weight and feather weight data.

weeks of age [19] [20] [50]. Consequently, Yalcin et al. [15] stated full feathered birds at $7 \mathrm{wk}$ of age. As reviewed by Leeson and Walsh [48], most estimates of feather percentage in adult birds range between 3\% and 6\% of BW. In laying hens, $6.4 \%$ to $7.0 \%$ feather DM of BW is reported [33]. Depending on age growing turkeys yielded $2.0 \%$ to $6.3 \%$ feathers as related to BW [51] or empty BW [52].

According to our present results, a very high individual variability of feather percentage can be expected in day old growing chickens. Similar data (Table 5) were calculated from earlier results as published by Lehmann [1], Stilborn et al. [50] and Sklan and Noy [53] [54]. In terms of fresh feather weight percentage related to the empty BW, feather proportion in fast growing chickens was 
Table 5. Feather percentage as related to the weekly final body weight (BW) of normally feathered broiler chickens dependent on age and gender.

\begin{tabular}{|c|c|c|c|c|c|c|c|c|}
\hline Age (d) & 1 & 7 & 14 & 21 & 28 & 35 & 42 & Literature source \\
\hline Female & 2.1 & & & & 5.2 & & & {$[1]^{1,2}$} \\
\hline Male & & 1.4 & 1.2 & 1.7 & 2.4 & 2.4 & 2.5 & \multirow{2}{*}[57]{$^{1,3}$} \\
\hline Female & & 1.2 & 1.7 & 2.3 & 2.9 & 3.1 & 3.0 & \\
\hline Male & 3.0 & & 3.1 & & 4.9 & & 5.2 & \multirow{2}{*}[50]{$^{1,4}$} \\
\hline Female & 3.4 & & 3.2 & & 5.4 & & 5.4 & \\
\hline Male & & 0.9 & 2.9 & 4.4 & 4.6 & 5.0 & 5.8 & \multirow{2}{*}[55]{$^{1,5}$} \\
\hline Female & & 1.3 & 3.2 & 4.9 & 5.2 & 5.6 & 6.8 & \\
\hline Male & 0.9 & & 2.4 & 4.7 & 3.9 & & 5.1 & [53] \\
\hline Male & 0.9 & 1.7 & 2.3 & 3.7 & 4.9 & 5.0 & 5.2 & [54] \\
\hline
\end{tabular}

${ }^{1}$ Calculated, based on reported body weight and feather weight data. ${ }^{2}$ Feather weight expressed as a percentage of the empty BW (Means of three different genotypes). ${ }^{3}$ Feather dry matter weight expressed as a percentage of the BW. ${ }^{4}$ Feather weight expressed as a percentage of the BW (Means of two different genotypes). ${ }^{5}$ Feather weight expressed as a percentage of the BW (Means of six different genotypes).

elevated non-linearly with increasing age and ranged between $1 \%$ and $3 \%$ at $\mathrm{d} 8$ to $3 \%$ and $5 \%$ at $\mathrm{d} 36$, respectively (Figure 1 ). These results are in general agreement with literature data (Table 5). According to Sklan and Noy [54], the feather proportion of BW in male broiler chickens is approximated by following equation: Feathers $(\%$ of $\mathrm{BW})=0.26 \cdot \mathrm{BW}^{0.38}$.

Generally, literature data in normally feathered growing chickens vary markedly. In addition to individual differences, both the absolutely certain description of bird's age and basis of reference (BW resp. feather-free BW) are the main factors responsible for high variation of feather percentage data. In consequence, data comparability is very limited. In majority of reported experiments feather weight was estimated by difference between BW before and after plucking. However, this procedure implies inaccuracies due to dry or wet de-feathering. Furthermore, the process of feather drying or the feather DM analysis and/or the analyses of feather-free body fraction are factors of influence. Table 2 and Table 3 provide an additional overview about the importance of reliable reference data impacting on derived feather percentage.

In line with Deschutter and Leeson [8], Moran [19] and Hancock et al. [55], feather growth of growing chicken also depends on gender (Table 2, Figure 1). The observed higher feather weight and feather percentage in female birds is in agreement with several reports [10] [41] [56] and gender-specific data [15] [19] [38] [42] [50] [55] [57] as summarized in Table 4 and Table 5. However, age dependent also similar or even less feather yields of female growing chickens are reported [3] [50]. But, due to the lower feather-free body mass and the lower surface area of female birds their feather mass per unit BW was higher as compared to their male counterparts of equal age. Otherwise, according to sex-linked different rate of feathering, feather loss of female birds during growth was observed to increase [57] [58]. 
As reviewed by Leeson and Walsh [9], the nutrient supply impacts on feather growth and development. Stimulated feather growth was observed with increasing dietary CP and SAA supply [18] [20] [22], mainly due to varying body proportion of feathers, connective tissue and muscle tissue [59]. Additionally, more feathers were found on the litter following a high protein diet [58] indicating faster feather development with subsequent moult. Otherwise, deficient feed and CP supply or imbalanced dietary AA composition created opposite effects on the rate of feathering of young birds [6] [7] [9] [21]. Feather percentage was significantly higher in restrictive fed birds as compared to birds fed on free choice level [6].

At d1, an elevated DM content in the feathers of freshly hatched chickens was observed (Table 3). Lehmann [2] indicated that down feathers are exceptional as related to age-depending changes of feather composition due to their high DM contents between $73 \%$ and $80 \%$ [1]. Smith and Bath [60] suggested that individual feathers of growing chickens reached maximum weight when the dry feather mass was $50 \%$ of the total mass. At 2 weeks of age all the feathers were half feather (50\% to 55\% DM) and half pulp (13-15\% DM) with approximately $38 \%$ to $40 \% \mathrm{DM}$ content in the entire feather [60]. According to Lehmann [1] [2] and Hancock et al. [55] the DM content of the feathers increased steadily throughout the growing period from $38 \%$ at week $1 \%$ to $63 \%$ DM at week $8-10$ indicating an apparent drying out of feathers with age [14]. Several reports [12] [35] [37] [61] underline our observed age-depending effect (Figure 2), but missing related data about the influence of gender on DM content in feathers.

Carcass DM content in the modern strain birds was significantly higher than in previous genotypes [62] [63] [64]. Significantly different DM contents of the feather-free or whole body of varying genotype broiler chickens are reported [1] [2] [42] [65] [66]. Increased DM content in fat-type chickens can be expected [67]. Accordingly, elevated body DM contents were observed with increasing age [1] [2] [61] [63] [65] [68] [69] [70] and in female versus male birds [3] [42] [62] [64].

Finally, energy and protein supply as well as dietary AA balance impact on DM content of the feather-free or total body of broiler chickens [42] [67]-[73], but eliminated in the current study by standardized diets.

\section{Conclusion}

Within the growth period of growing chickens, the feather coverage as a proportion of the total or empty body mass increases with increasing age of the birds. Due to larger relative feather percentage in female vs. male birds, gender-specific differences were observed and also validated by literature data. With increasing age, the DM content in feathers and in feather-free or whole empty body raised continuously, but DM content of feathers differed not significantly between male and female birds. However, the whole body of female birds contained significantly more DM as compared to their male counterparts. The observed age and 
gender-specific proportion between feather and feather-free body fractions and modulation of DM contents during growth are of special importance for evaluating energy and nutrient requirements based on factorial procedures. For this purpose, additional data are needed to specify the database. In consequence, further detailed data about nutrient composition of feathers and feather-free body, but also about nutrient deposition depending on age and gender in modern genotype growing chickens are required. Actually, a consecutive publication is prepared to provide such a database for re-evaluation of requirement data in modern genotype meat-type chickens.

\section{References}

[1] Lehmann, F. (1939) Schlachtversuche mit Masthühnern. [Slaughtering Studies with Fattening Fowls.] Archiv für Geflügelkunde, 13, 1-36.

[2] Lehmann, F. (1940) Beiträge zur Theorie der Junggeflügelmast. [Contributions to the Concept of Fattening of Chickens.] Archiv für Kleintierzucht, 1, 1-45.

[3] Gous, R.M., Moran Jr., E.T., Stilborn, H.R., Bradford, G.D. and Emmans, G.C. (1999) Evaluation of the Parameters Needed to Describe the Overall Growth, the Chemical Growth, and the Growth of Feathers and Breast Muscles of Broilers. Poultry Science, 78, 812-821. https://doi.org/10.1093/ps/78.6.812

[4] Silva, E.P., Sakomura, N.K., Dorigam, J.C.P., Donato, D.C.Z., Malheiros, E.B. and Fernandes, J.B.K. (2013) Efficiency of Utilization of Methionine + Cystine on Pullets. $19^{\text {th }}$ European Symposium on Poultry Nutrition, Potsdam, Germany, File 50, $1-4$.

[5] Bonato, M.A., Sakomura, N.K., Gous, R.M., Silva, E.P., Soares, L. and Peruzzi, N.J. (2016) Description of a Model to Optimise the Feeding of Amino Acids to Growing Pullets. British Poultry Science, 57, 123-133. https://doi.org/10.1080/00071668.2015.1127892

[6] Wylie, L.M., Robertson, G.W., MacLeod, M.G. and Hocking, P.W. (2001) Effects of Ambient Temperature and Restricted Feeding on the Growth of Feathers in Growing Turkeys. British Poultry Science, 42, 449-455. https://doi.org/10.1080/00071660120070631

[7] Wylie, L.M., Robertson, G.W. and Hocking, P.W. (2003) Effects of Dietary Protein Concentration and Specific Amino Acids on Body Weight, Body Composition and Feather Growth in Young Turkeys. British Poultry Science, 44, 75-87. https://doi.org/10.1080/0007166031000085346

[8] Deschutter, A. and Leeson, S. (1986) Feather Growth and Development. World's Poultry Science Journal, 42, 259-267. https://doi.org/10.1079/WPS19860020

[9] Leeson, S. and Walsh, T. (2004) Feathering in Commercial Poultry. II. Factors Influencing Feather Growth and Feather Loss. World's Poultry Science Journal, 60, 52-63. https://doi.org/10.1079/WPS20034

[10] Siegel, P.B. (1963) Selection for Body Weight at Eight Weeks of Age. 2. Correlated Responses of Feathering, Body Weights and Reproductive Characteristics. Poultry Science, 42, 896-905. https://doi.org/10.3382/ps.0420896

[11] Lowe, P.C. and Merkley, J.W. (1986) Association of Genotypes for Rate of Feathering in Broilers with Production and Carcass Composition Traits. Effect of Genotypes, Sex, and Diet on Growth and Feed Conversion. Poultry Science, 65, 1853-1858. https://doi.org/10.3382/ps.0651853 
[12] Cahaner, A., Dunnington, E.A., Jones, D.E., Cherry, J.A. and Siegel, P.B. (1987) Evaluation of Two Commercial Broiler Male Lines Differing in Efficiency of Feed Utilization. Poultry Science, 66, 1101-1110. https://doi.org/10.3382/ps.0661101

[13] Leclercq, B., Chagneau, A.M., Cochard, T. and Khoury, J. (1994) Comparative Responses of Genetically Lean and Fat Chickens to Lysine, Arginine and Non-Essential Amino Acid Supply. I. Growth and Body Composition. British Poultry Science, 35, 687-696. https://doi.org/10.1080/00071669408417735

[14] Martin, P.A., Bradford, G.D. and Gous, R.M. (1994) A Formal Method of Determining the Dietary Amino Acid Requirements of Laying-Type Pullets during Their Growing Period. British Poultry Science, 35, 709-724. https://doi.org/10.1080/00071669408417737

[15] Yalcin, S., Settar, P., Ozkan, S. and Cahaner, A. (1997) Comparative Evaluation of Three Commercial Broiler Stocks in Hot versus Temperate Climates. Poultry Science, 76, 921-929. https://doi.org/10.1093/ps/76.7.921

[16] Yunis, R. and Cahaner, A. (1999) The Effects of the Naked Neck (Na) and Frizzle $(F)$ Genes on Growth and Meat Yield of Broilers and Their Interactions with Ambient Temperatures and Potential Growth Rate. Poultry Science, 78, 1347-1352. https://doi.org/10.1093/ps/78.10.1347

[17] Kalinowski, A. and Corzo, A. (2004) The Impact of Dietary Protein and Amino Acids on Feather Development and Carcass Quality. In: Zimmermann, N.G., Ed., Proceedings of the 2nd Mid-Atlantic Nutrition Conference, University of Maryland, College Park, 120-127.

[18] Patel, M.B., Bishawi, K.O., Nam, C.W. and McGinnis, J. (1980) Effect of Drug Additives and Type of Diet on Methionine Requirement for Growth, Feed Efficiency, and Feathering of Broilers Reared in Floor Pens. Poultry Science, 59, 2111-2120. https://doi.org/10.3382/ps.0592111

[19] Moran, E.T. (1981) Cystine Requirement of Feather-Sexed Broiler Chickens with Sex and Age. Poultry Science, 60, 1056-1061. https://doi.org/10.3382/ps.0601056

[20] Pesti, G.M., Leclercq, B., Chagneau, A.-M. and Cochard, T. (1996) Effects of the Naked Neck ( $\mathrm{Na}$ ) Gene on the Sulphur-Containing Amino Acid Requirements of Broilers. Poultry Science, 75, 375-380. https://doi.org/10.3382/ps.0750375

[21] Si, J., Fritts, C.A., Burnham, D.J. and Waldroup, P.W. (2004) Extent to Which Crude Protein May Be Reduced in Corn-soybean Meal Broiler Diets through Amino Acid Supplementation. International Journal of Poultry Science, 3, 46-50. https://doi.org/10.3923/ijps.2004.46.50

[22] Urdaneta-Rincon, M. and Leeson, S. (2004) Effect of Dietary Crude Protein and Lysine on Feather Growth in Chicks to Twenty-One Days of Age. Poultry Science, 83, 1713-1717. https://doi.org/10.1093/ps/83.10.1713

[23] Van Emous, R.A., Kwakkel, R., van Krimpen, M. and Hendriks, W. (2015) Effects of Different Dietary Protein Levels during Rearing and Different Dietary Energy Levels During Lay on Behaviour and Feather Cover in Broiler Breeders Females. Applied Animal Behaviour Science, 168, 45-55.

[24] Zeng, Q.F., Zhang, Q., Chen, X., Doster, A., Murdoch, R., Makagon, M., Gardner, A. and Applegate, T.J. (2015) Effect of Dietary Methionine Content on Growth Performance, Carcass Traits, and Feather Growth of Pekin Duck from 15 to 35 Days of Age. Poultry Science, 94, 1592-1599. https://doi.org/10.3382/ps/pev117

[25] Kabuß, V.-L., Kölln, M., Helmbrecht, A., Meißner, J. and Kamphues, J. (2017) Effects of Different Dietary Methionine Levels on Performance and Skin Health in Growing Turkeys. Proceedings of the Society of Nutrition Physiology, 26, 86. 
[26] Fisher, H., Scott, H.M. and Johnson, B.C. (1955) The Role of Glycine in Chick Nutrition. The Journal of Nutrition, 55, 415-430.

[27] Leong, K.C., Sunde, M.L., Bird, H.R. and Elvehjem, C.A. (1959) Interrelationship among Dietary Energy, Protein, and Amino Acids for Chickens. Poultry Science, 38, 1267-1285. https://doi.org/10.3382/ps.0381267

[28] Anderson, J.O. and Warnick, R.E. (1967) Gross Abnormalities in Chicks Fed Amino Acid Deficient Diets. Poultry Science, 46, 856-862. https://doi.org/10.3382/ps.0460856

[29] Robel, E.J. (1977) A Feather Abnormality in Chicks Fed Diets Deficient in Certain Amino Acids. Poultry Science, 56, 1968-1971. https://doi.org/10.3382/ps.0561968

[30] Farran, M.T. and Thomas, O.P. (1992) Valine Deficiency. 1. The Effect of Feeding a Valine-Deficient Diet during the Starter Period on Performance and Feather Structure of Male Broiler Chicks. Poultry Science, 71, 1879-1884. https://doi.org/10.3382/ps.0711879

[31] Gruber, K., Roth, F.X. and Kirchgeßner, M. (2000) Effect of Partial Dietary Amino Acid Deductions on Growth Rate and Nitrogen Balance in Growing Chicks. Archiv für Geflügelkunde, 64, 244-250.

[32] Roth, F.X., Gruber, K. and Kirchgeßner, M. (2001) The Ideal Dietary Amino Acid Pattern for Broiler-Chicks of Age 7 to 28 Days. Archiv für Geflügelkunde, 65, 199-206.

[33] Männer, K. (1991) Energy Metabolism of Laying Hens of Different Genotypes Exposed to High Ambient Temperatures. 1. Report: Influence of the Gene for Naked Neck (Na) on Performance and Energy Metabolism of Normal and Dwarfed Laying Hens (In German). Archiv für Geflügelkunde, 55, 247-257.

[34] Männer, K. (1992) Energy Metabolism of Laying Hens of Different Genotypes Exposed to High Ambient Temperatures. 2nd Report: Influence of the Gene for Curling of Feathers (F) on Performance and Energy Metabolism of Full vs. Partly Feathered Normal and Dwarfed Laying Hens. (In German). Archiv für Geflügelkunde, $56,8-13$.

[35] Cahaner, A., Deeb, N. and Gutman, M. (1993) Effect of the Plumage-Reducing Naked Neck (Na) Gene on the Performance of Fast-Growing Broilers at Normal and High Ambient Temperatures. Poultry Science, 72, 767-775. https://doi.org/10.3382/ps.0720767

[36] Deeb, N. and Cahaner, A. (1999) The Effects of Naked Neck Genotypes, Ambient Temperature, and Feeding Status and Their Interactions on Body Temperature and Performance of Broilers. Poultry Science, 78, 1341-1346. https://doi.org/10.1093/ps/78.10.1341

[37] Singh, C.V., Kumar, D. and Singh, Y.P. (2001) Potential Usefulness of the Plumage Reducing Naked Neck (Na) Gene in Poultry Production at Normal and High Ambient Temperatures. World s Poultry Science Journal, 57, 139-156. https://doi.org/10.1079/WPS20010011

[38] Patra, B.N., Bais, R.K.S., Prasad, R.B. and Singh, B.P. (2002) Performance of Naked Neck versus Normally Feathered Coloured Broilers for Growth, Carcass Traits and Blood Biochemical Parameters in Tropical Climate. Asian-Australasian Journal of Animal Science, 15, 1776-1783. https://doi.org/10.5713/ajas.2002.1776

[39] N'dri, A.L., Mignon-Grasteau, S., Sellier, N., Beaumont, C. and Tixier-Boichard, M. (2007) Interaction between the Naked Neck Gene, Sex, and Fluctuating Ambient Temperature on Heat Tolerance, Growth, Body Composition, Meat Quality, and Sensory Analysis of Slow Growing Meat-Type Broilers. Livestock Science, 110, 
33-45.

[40] Cahaner, A., Ajuh, J.A., Siegmund-Schultze, M., Azoulay, Y., Druyan, S. and Valle Zarate, A. 2008) Effects of the Genetically Reduced Feather Coverage in Naked Neck and Featherless Broilers on Their Performance under Hot Conditions. Poultry Science, 87, 2517-2527. https://doi.org/10.3382/ps.2008-00284

[41] Sheridan, A.K. and McDonald, M.W. (1963) The Relationship between Feathering and Body Weight in Broiler Chickens. Poultry Science, 42, 1468-1471. https://doi.org/10.3382/ps.0421468

[42] Ajang, O.A., Prijono, S. and Smith, W.K. (1993) Effect of Dietary Protein Content on Growth and Body Composition of Fast and Slow Feathering Broiler Chickens. British Poultry Science, 34, 73-91. https://doi.org/10.1080/00071669308417564

[43] NRC (1994) Nutrient Requirements of Poultry. 9th Revised Edition, National Research Council, National Academy Press, Washington DC.

[44] GRRS (German Recommendations for Requirement Standards) Gesellschaft für Ernährungsphysiologie, Ausschuss für Bedarfsnormen (1999) Empfehlungen zur Energie-und Nährstoffversorgung der Legehennen und Masthühner (Broiler). DLG-Verlags-GmbH, Frankfurt am Main.

[45] Wecke, C. and Liebert, F. (2013) Improving the Reliability of Optimal In-Feed Amino Acid Ratios Based on Individual Amino Acid Efficiency Data from N Balance Studies in Growing Chicken. Animals, 3, 558-573. https://doi.org/10.3390/ani3030558

[46] WPSA (1984) The Prediction of Apparent Metabolizable Energy Values for Poultry in Compound Feeds. World s Poultry Science Journal, 40, 181-182.

[47] Naumann, C. and Bassler, R. (1976-2004) Die chemische Untersuchung von Futtermitteln. Methodenbuch, Volume III, VDLUFA-Verlag, Darmstadt.

[48] Leeson, S. and Walsh, T. (2004) Feathering in Commercial Poultry. I. Feather Growth and Composition. World s Poultry Science Journal, 60, 42-51. https://doi.org/10.1079/WPS20033

[49] Wheeler, K.B. and Latshaw, J.D. (1981) Sulfur Amino Acid Requirements and Interactions in Broilers during Two Growth Periods. Poultry Science, 60, 228-236. https://doi.org/10.3382/ps.0600228

[50] Stilborn, H.L., Moran, Jr., E.T., Gous, R.M. and Harrison, M.D. (1994) Experimental Data for Evaluating Broiler Models. The Journal of Applied Poultry Research, 3, 379-390. https://doi.org/10.1093/japr/3.4.379

[51] Hurwitz, S., Frisch, Y., Bar, A., Eisner, U., Bengel, I. and Pines, M. (1983) The Amino Acid Requirements of Growing Turkeys. 1. Model Construction and Parameter Estimation. Poultry Science, 62, 2208-2217.

https://doi.org/10.3382/ps.0622208

[52] Rivera-Torres, V., Noblet, J. and van Milgen, J. (2011) Changes in Chemical Composition in Male Turkeys during Growth. Poultry Science, 90, 68-74. https://doi.org/10.3382/ps.2010-00633

[53] Sklan, D. and Noy, Y. (2004) Catabolism and Deposition of Amino Acids in Growing Chicks: Effect of Dietary Supply. Poultry Science, 83, 952-961. https://doi.org/10.1093/ps/83.6.952

[54] Sklan, D. and Noy, Y. (2005) Direct Determination of Optimal Amino Acid Intake for Maintenance and Growth in Broilers. Poultry Science, 84, 412-418. https://doi.org/10.1093/ps/84.3.412

[55] Hancock, C.E., Bradford, G.D., Emmans, G.C. and Gous, R.M. (1995) The Evalua- 
tion of the Growth Parameters of Six Strains of Commercial Broiler Chickens. British Poultry Science, 36, 247-264. https://doi.org/10.1080/00071669508417773

[56] McDougald, L.R. and Keshavarz, K. (1984) The Effect of Polyether, Ionophorous Anticoccidial Drugs an Feather Growth in Genetically Slow-Feathering Broilers. Poultry Science, 63, 1322-1326. https://doi.org/10.3382/ps.0631322

[57] Fisher, M.-L., Leeson, S., Morrison, W.D. and Summers, J.D. (1981) Feather Growth and Feather Composition of Broiler Chickens. Canadian Journal of Animal Science, 61, 769-773. https://doi.org/10.4141/cjas81-093

[58] Twinging, Jr., P.V., Thomas, O.P. and Bossard, E.H. (1976) The Number of Feathers on the Litter; Another Criterion for Evaluating the Adequacy of Broiler Diets. Poultry Science, 55, 1200-1207. https://doi.org/10.3382/ps.0551200

[59] Kreuzer, M., Kirchgeßner, M. and Steinhart, H. (1988) Effect of the Level of Energy and Protein Supply, Respectively of Age on the Amino Acid Composition of Broiler Chicks (In German). Archiv für Geflügelkunde, 52, 133-141.

[60] Smith, W.K. and Bath, H.M. (1995) Growth and Composition of Feathers in Male Broilers. British Poultry Science, 36, 874.

[61] Conde-Aguilera, J.A., Cobo-Ortega, C., Tesseraud, S., Lessire, M., Mercier, Y. and van Milgen, J. (2013) Changes in Body Composition in Broilers by a Sulphur Amino Acid Deficiency during Growth. Poultry Science, 92, 1266-1275. https://doi.org/10.3382/ps.2012-02796

[62] Chambers, J.R., Gavora, J.S. and Fortin, A. (1981) Genetic Changes in Meat-Type Chickens in the Last Twenty Years. Canadian Journal of Animal Science, 61, 555-563. https://doi.org/10.4141/cjas81-067

[63] Havenstein, G.B., Ferket, P.R., Scheideler, S.E. and Rives, D.V. (1994) Carcass Composition and Yield of 1991 vs. 1957 Broilers When Fed "Typical" 1957 and 1991 Broiler Diets. Poultry Science, 73, 1795-1804. https://doi.org/10.3382/ps.0731795

[64] Havenstein, G.B., Ferket, P.R. and Qureshi, M.A. (2003) Carcass Composition and Yield of 1957 Versus 2001 Broilers When Fed Representative 1957 and 2001 Broiler Diets. Poultry Science, 82, 1509-1518. https://doi.org/10.1093/ps/82.10.1509

[65] Somes, Jr., R.G. and Johnson, S. (1982) The Effect of Scaleless Gene, Sc, on Growth Performance and Carcass Composition of Broilers. Poultry Science, 61, 414-423. https://doi.org/10.3382/ps.0610414

[66] Hanzl, C.J. and Somes, Jr., R.G. (1983) The Effect of the Naked Neck Gene, Na, on Growth and Carcass Composition of Broilers Raised in Two Temperatures. Poultry Science, 62, 934-941. https://doi.org/10.3382/ps.0620934

[67] Geraert, P.A., Macleod, M.G., Larbier, M. and Leclercq, B. (1990) Nitrogen Metabolism in Genetically Fat and Lean Chickens. Poultry Science, 69, 1911-1921. https://doi.org/10.3382/ps.0691911

[68] Gerum, J. and Kirchgeßner, M. (1978) Protein, Fat and Energy Deposition of Two Weeks Old Broilers with Varying Energy and Protein Supply (In German). Archiv für Geflügelkunde, 42, 22-28.

[69] Kirchgeßner, M., Roth-Maier, D.A. and Gerum, J. (1978) Body Composition and Nutrient Deposition of 3-5 Week Old Broilers with Varying Energy and Protein Supply (In German). Archiv für Geflügelkunde, 42, 62-69.

[70] Nieß, E., Hamid, I.I. and Pfeffer, E. (2003) Effect of Non Essential Amino Acid Supply on the Deposition of Protein and Lipids in Broiler Chicks. Archiv für Ge- 
flügelkunde, 67, 167-174.

[71] Velu, J.G., Scott, H.M. and Baker, D.H. (1972) Body Composition and Nutrient Utilization of Chicks Fed Amino Acid Diets Containing Graded Amounts of Either Isoleucine or Lysine. Journal of Nutrition, 102, 741-748.

[72] Deschepper, K. and De Groote, G. (1995) Effect of Dietary Protein, Essential and Non-Essential Amino Acids on the Performance and Carcase Composition of Male Broiler Chickens. British Poultry Science, 36, 229-245.

https://doi.org/10.1080/00071669508417772

[73] Bregendahl, K., Sell, J.L. and Zimmerman, D.R. (2002) Effect of Low-Protein Diets on Growth Performance and Body Composition of Broiler Chicks. Poultry Science, 81, 1156-1167. https://doi.org/10.1093/ps/81.8.1156 